\title{
Rural electrification in India: Galilee Basin coal versus decentralised renewable energy micro grids
}

\author{
Lynette Molyneaux $^{1}$, Liam Wagner ${ }^{2}$, John Foster ${ }^{1}$ \\ ${ }^{1}$ Energy Economics and Management Group, University of Queensland, Brisbane, Australia * \\ ${ }^{2}$ Economics, Griffith Business School, Griffith University, Brisbane, Australia
}

\section{Highlights}

- Compares centralised coal generation and decentralised renewable energy

- Rural renewable energy investment is equivalent to centralised imported coal option

- Pollution costs of coal emissions makes renewable generation more attractive

- Employment benefits from rural electrification will drive rural development

- Centralised generation a poor fit for rural load requirement

\begin{abstract}
The state of Bihar in India has approximately 75 million people with no access to electricity. The government of India has pursued a policy of rural electrification through the provision of centralised coal-fired power which has been unable to resolve the low levels of electrification. Coal supply woes in India have led Indian companies to pursue new coal mines in Australia's Galilee Basin. The costs of these mining ventures will be high due to the mining infrastructure required and long transport distances to rural India. A high level analysis of mining, transport and power station investment to meet rural demand in Bihar shows that the absolute investment requirement using coal, especially coal sourced from Australia, as an expensive option. Pursuing electrification through village level, renewable energy micro-systems requires lower financing and provides more flexibility. Pollution costs associated with coal-fired generation, employment benefits associated with many village implementations and a rural load unsupported by industry load, show the benefit associated with decentralised, renewable energy electrification.
\end{abstract}

\section{Keywords}

Rural electrification

Renewable energy

Distributed energy

JEL Classification:

Q42; Q53; R51

Word count: 7,992

\footnotetext{
${ }^{* *}$ Corresponding author: phone number: +617 336-61003, email address: I.molyneaux@uq.edu.au
} 


\section{INTRODUCTION}

"Advancing social and economic progress with clean energy is the role of leaders globally. India is a prime example of a nation exerting its right to grow and creating energy access for all of its citizens. Clean energy from coal is a major part of the solution and will be essential to achieving that goal". For proposing to use coal to eliminate energy poverty, Peabody Energy was awarded an Energy and Environment Foundation Global Excellence Award this year (Peabody Energy, 2015). Peabody's senior vice president has pointed to Australia as having "the global leadership to create solutions that will help combat energy poverty, increase access to low-cost electricity and improve emissions to achieve our environmental goals" (Svec, 2014). This view is tacitly supported by many.

Coal is credited with powering the industrial revolution but evidence that coal improves emissions and achieves environmental goals is scant. Certainly the industrial revolution improved quality of life for the middle and upper classes, but conditions for the working poor who moved to the towns in search of work were abysmal. For the urban poor it meant pollution, urban squalor and illness. A government report from the 1840 's noted that the smoke in Manchester had "risen to an intolerable pitch, and is annually increasing, the air is rendered visibly impure..."(Freese, 2006, P81). The life expectancy of a rural working person in England was 38 years, whilst that in Manchester, was 17 years due to more than $57 \%$ of children dying before they turned five. The "inky canopy which seemed to embrace and involve the entire place"(Freese, 2006, P81), played its part in the epidemic of rickets, a disease that results from a lack of direct sunlight, that befell Manchester. The recruitment drive for the Crimean War rejected $42 \%$ of the urban recruits because of bronchial diseases and rickets (Freese, 2006).

Although London was not as industrialised as Manchester, it did have a population of 3 million that used coal for heating. Pollution from coal fires, under certain cold and windless conditions, facilitated the famous London smog. Analysis of severe fog events and death statistics showed deaths of $270-700$ in $1873,700-1100$ in 1880,1000 in 1892 . The health consequences of the fogs 
were ignored because no formal link was made between coal emissions and lung problems until 1914 (Freese, 2006). In 1952 a particularly severe fog led to more than 4000 deaths, bronchial problems and economic disruption. The Clean Air Act of 1956 followed to control coal emissions including restrictions on the use of coal for heating in homes (MetOffice, 2015). The USA passed the Clean Air Act of 1970 which similarly sought to control pollution from burning coal. What was learnt over the 100 years of coal use to power development was that it was only acceptable if the coal was burnt away from densely populated urban areas so that emissions could be dispersed and diluted to limit impact on human health.

Decades later China deployed coal to fuel development but the health implications for the Chinese have been severe. The drag on the economy from airborne pollution is estimated to have decreased consumption and resulted in welfare loss of between 5 and 14\% to the Chinese economy (Matus et al., 2012). China's Health Minister from 2007 to 2013, a professor of medicine and molecular biologist, has stated that lung cancer is now the leading cause of death in China and that 350,000 to 500,000 people die prematurely annual as a result of pollution. Consequently, China is preparing to spend US\$278 billion over the next 5 years in an attempt to control pollution (Chen et al.).

Despite the impact on health and well-being associated with reliance on coal for energy use, India seeks to use coal for development. Indian power companies are not able to source enough coal domestically for this purpose, causing them to look to international sources. Adani, an Indian company, has invested in ports and power companies in India and mining ventures in Indonesia and Australia. Their Indonesian mine started producing coal in 2013, and in 2014 their Australian venture received approval to proceed from the Queensland Co-ordinator General.

The Galilee Basin in Queensland contains a very large reserve of coal but without easy access to markets. Adani purchased land and a mining license in the Galilee Basin for around \$635million in 2010, followed by the purchase of the Abbot Point Coal Terminal from the Queensland Government in 2011 for AU\$1.8bn. In order to export coal to India, Adani's Galilee Project proposes further 
investments of: AU\$16 bn on developing and operating the Carmichael Coal Mine over 60 years; AU\$1.2bn on building a rail corridor to the closest existing rail networks; and expanding the Abbot Point Coal Terminal to accommodate the processing of an additional 60 million tonnes per annum (mtpa) of coal (GHD Pty Ltd, 2013).

This paper looks at the costs associated with a large mine development, multiple coal transportation systems, a fleet of coal-fired power stations and the network infrastructure required to distribute power to those without access to electricity in India. It compares this with the costs of decentralised, renewable energy micro-grid systems to ascertain which option provides the greater benefit. The methods are outlined in section 2, and the results in section 3 with section 4 providing discussion around the results. Section 5 concludes.

\section{METHODS}

Data including: the mine investment; transportation investments; power station investment and operational costs; network infrastructure investment, renewable energy potential and demographics are all sourced from public sources as detailed in each of the sections below.

The health costs associated with coal burning are considerable. With China in the throes of counting the costs associated with coal pollution, evidence from China is used as a benchmark to estimate the costs that may be experienced by India pursuing the same course.

\subsection{Comparing options using Levelised cost}

Levelised cost over the life of the projects is used to compare the different options for Bihar because it allows for comparison between varying costs and levels of production over different technical lifetimes. The methodology ensures that investment and operating costs are discounted over varying lifetimes to their present values. Capital-intensive technologies are very sensitive to discount rates which means that the risk profile of projects need to be reflected in the discount rate. To calculate a discount rate relevant to the risk profile of these projects, the Weighted Average Cost of Capital 
(WACC) is calculated using a model based on Capital Asset Pricing Model (CAPM) theory. The WACC estimates the rate that a company is expected to pay on average to all its security holders to finance its investments.

\subsubsection{Calculation of WACC}

The WACC is calculated by estimating the effects of inflation, taxation, risk free rates of return, cost of equity risk premium, cost of debt risk premium, asset price risk and corporate debt to equity ratios for operations in Australia as well as in India on the discount rate. The variables listed in Table 1 are used in the calculation of WACC and LCOE.

\subsubsection{Inflation pass through rates}

The pass through rates $(\rho)$ for inflation are set at $\rho_{r}=0.75$ for revenue streams and $\rho_{c}=100 \%$ for cost streams for non-financial operating assets. The prevailing inflation rates (CPI) for Australia and India have been sourced from the national reserve banks' base target inflation rates i.e. $2.5 \%$ and $5.7 \%$ respectively. The pass through rates are applied onto the cost and revenue streams such that in year $t$,

$$
C P I(t)_{R}=\left\{[1+(C P I / 100)] * \rho_{R}\right\}^{t}, C P I(t)_{C}=\left\{[1+(C P I / 100)] * \rho_{C}\right\}^{t}
$$

\subsubsection{Taxation}

The corporate tax rate in Australia is set at 30\% (KPMG, 2015), and following the application of deductible items such as interest payments and imputation credits, the effective tax rate is assumed to fall to $22.5 \%$ (Simshauser and Wild, 2009). The prevailing taxation rate for companies in India is currently 33.99\% (KPMG, 2015). Interest payments and the like are allowable deductible items, however the minimum tax rate allowable under Indian corporate tax law is set at $18.5 \%$ (Bloomberg, 2015a). 


\subsubsection{Risk free rate of return}

The risk free Rate of Return (RoR) has been calculated by taking the previous 20 day average of the 10 year government bond rates (Australia 3.72\% and India 7.7\%) (Bloomberg, 2015b).

\subsubsection{Equity risk premium}

The equity risk premium is central to establishing the required rates of return to establish the WACC (Damodaran, 2013) and its use in the CAPM. For the Australian assets a benchmark $6 \%$ is used for the equity risk premium (Queensland Competition Authority, 2013). With the Indian assets (specifically electricity generation options), the equity risk premium is derived from first principles. While India is an emerging economy, it has a very mature equity market (Choudhary and Choudhary, 2010). The methodology as proposed by (Damodaran, 2013) is used to calculate the required equity premium. As of March 2015 the country credit/risk rating for India is BBB (S\&P, 2015) and the credit default swap premium of $3.5 \%$. The scaled equity risk premium is $9.25 \%$ and the required market rate of return is $16.95 \%$.

\subsubsection{Debt risk premium}

The debt basis point premium for the coal mine in Australian has been estimated at 295 basis points, via the standard regulatory agency guidelines for $\mathrm{BBB}+$ rated corporate lending requirements (S\&P, 2015). The electricity generation asset premium in India has been derived from the prevailing 330 basis point from the prevailing country risk premium (Damodaran, 2013). The cost of debt $\left(R_{d}\right)$, for the Australian and Indian operations, is derived as $6.67 \%$ and $11 \%$ respectively.

\subsubsection{Asset risk}

The asset Gamma $(\Gamma)$, equity beta $\left(\beta_{a}\right)$ and the debt beta $\left(\beta_{d}\right)$, for the Adani operations in Australia have been sourced from the Queensland Competition Authority (QCA) as is the standard practice for assessing these types of projects (Queensland Competition Authority, 2013). The equity beta $\left(\beta_{e}\right)$, is then calculated via the Monkhouse formula which is as follows: 


$$
\beta_{e}=\beta_{a}+\left(\beta_{a}-\beta_{d}\right) *\left(1-R_{d} /\left(1+R_{d}\right) * T\right) * D / E=1.6
$$

The equivalent values for the Adani electricity generation options in India need to be carefully constructed given the greater amount of uncertainty for investing in the power sector in a developing nation. Firstly the asset Gamma is simply the imputation credit effect on taxation rates, which, given the minimum level of expected taxation is set at $18.5 \%$, remains at 0.5 . Secondly, as we are unable to directly assess the level of risk associated with the underlying equity of this corporation we have sought from the literature the standard value of 1.91 which is a function of expected leverage (Damodaran, 2013). This in turn allows debt beta of -0.497 to be derived.

Given exogenous input of beta equity for Indian operations, the expected asset beta can be derived as a measure of underlying asset risks as follows:

$$
\beta_{a}=\beta_{e} *(E / E+((1-T) * D))=0.86
$$

This is consistent with the calculations as presented in (Damodaran, 2015) for the Indian power sector.

\subsubsection{Return on Equity}

The required return on equity for the CAPM is calculated via the following equation:

$$
R_{e}=R_{f}+\beta_{e}\left(R_{m}-R_{f}\right)
$$

\subsubsection{WACC}

The post-tax real WACC is used in a similar fashion as proposed by the international and Australian finance and energy literature (Simshauser and Wild, 2009) as a conservative proxy for investment decision hurdle rate. The post-tax WACC has been applied because of the effects of depreciation on capital intensive mining and electricity generation assets. Its calculation is as follows:

$$
W_{\text {ACC }} C_{\text {Post Tax Nominal }}=E / V * R_{e}\left(\left(1-T_{e}\right) /\left(1-T_{e}(1-\Gamma)\right)\right)+D / V * R_{d}\left(1-T_{e}\right) .
$$


The Fisher equation allows for the conversion of the WACC into real terms, which accounts for inflationary effects over the economic life of the project assets (Acil Tasman, 2009) and is formulated via:

$$
W_{A C C_{\text {Post-Tax Real }}}=\left(1+\text { WACC }_{\text {Post Tax Nominal }} /\left(1+C P I_{C}\right)\right)-1
$$

\subsubsection{Calculation of Levelised Cost of Energy (LCOE)}

After calculation of the WACC, LCOE is established using the following equation:

$\mathrm{LCOE}=\left(I N V+\sum_{n=1}^{N} \frac{V O M}{(1+W A C C)^{N}}+\frac{F O M}{(1+W A C C)^{N}}+\sum_{n=1}^{N} \frac{F C}{(1+W A C C)^{N}}\right) /\left(\left(\sum_{n=1}^{N} \frac{\text { hours } * \sum_{n=1}^{N}(P * C F)}{(1+W A C C)^{N}}\right) / A U X\right)$

Where:

$\begin{array}{ll}\text { WACC } & \text { Weighted Average Cost of Capital } \\ \text { INV } & \text { Capital cost of investment }(\$ / \mathrm{kW}) \\ \text { VOM } & \text { Variable Operating and Maintenance costs for plant }(\$ / \mathrm{MWh}) \\ \text { FOM } & \text { Annual Fixed Costs for plant }(\$ \mathrm{~m}) \\ \text { FC } & \text { Fuel Costs for plant }(\$ / \mathrm{MWh}) \\ N & \text { Economic Lifetime } \\ P & \text { Capacity of plant in MW } \\ \text { CF } & \text { Capacity factor of plant } \\ \text { AUX } & \text { Auxiliary use of Power Station }\end{array}$

A more detailed explanation of the specifics required for LCOE calculations for power stations can be found in (Wagner and Foster, 2011), and a comparison of the theoretical frameworks for LCOE calculations is available in (Foster et al., 2014).

\subsubsection{Calculation of Long Run Marginal Cost of coal}

After calculation of the WACC, Long Run Marginal Cost (LRMC) for coal including investment in the mine, rail and port is calculated using the following equation:

$$
\operatorname{LRMC}=\left(\sum_{n=1}^{N} I N V(n)+\sum_{n=1}^{N} \frac{V_{n}}{(1+W A C C)^{N}}+\frac{F_{n}}{(1+W A C C)^{N}}\right) /\left(\sum_{n=1}^{N} \frac{\sum_{n=1}^{N}(Q(n))}{(1+W A C C)^{N}}\right)
$$

Where:

$Q(n)$ production capacity within year $n$

$\operatorname{INV}(n)$ capital investment in year $n$

$V_{n} \quad$ variable costs associated with production in year $n$

$F_{n} \quad$ fixed costs associated with the production system in year $n$ 


\subsubsection{Exchange rate assumptions}

Constant exchange rates used are Rupees 60 to US\$1, and AU\$1.25 to US\$1. In general, $\$$ costs should be assumed to be US \$ unless otherwise indicated.

\subsection{India's requirement for electricity}

An estimated 400 million people living in 80 million households in India have no access to electricity. Those without electricity tend to be in rural locations but there are 3 states that have very low levels of household electrification, namely: Odisha with $43 \%$, Assam with $37 \%$ and Bihar with $16 \%$. Bihar's statistic is noteworthy because it has a large population of 104 million people, of which $89 \%$ live in rural areas, with the lowest female literacy rates (+7 years) in the country of $64 \%$ and the lowest Net State Domestic Product per person of Rs32954/annum (approximately US\$550/annum) (Planning Commission, 2014b). Bihar represents nearly $20 \%$ of the Indian population without access to electricity, making it a good case study on the costs of electrification.

Provision of electricity in Bihar is dismal. To service its 5.6 million customers the state provides domestic generation capacity of 544MW. The state electricity department also sources power from National Thermal Power Corporation (NTPC), an Indian Government owned corporation, (which allocates to Bihar $1.3 \mathrm{GW}$ from its $3.2 \mathrm{GW}$ of generation located in Bihar, the rest being allocated to the other Eastern states) and from generators in the surrounding states, at high tariffs to meet local demand. Transmission and distribution losses have been as high as $44 \%$ in recent years.

Rural electrification policy in Bihar, as in all Indian states, has been to invest in transmission and distribution infrastructure to every village. Significant resources have been poured into the $100 \%$ electrification program and statistics claim that $89 \%$ of villages in Bihar now have access to power (Planning Commission, 2014a). The village electrification program made no allowance for metering or oversight, which enabled savvy village consumers to gain access to electricity illegally. Equally, measurement of the progress of the electrification program makes no allowances for deelectrification as a result of transformer failure, equipment theft or other reasons. Studies 
conducted in some districts in Bihar indicate that $50 \%$ of electrified villages have at some stage been de-electrified, with only $45 \%$ of the de-electrified villages re-electrified (Oda and Tsujita, 2014).

Historically, tariffs for domestic and agricultural users have been held low, leading to severe financial problems for the State electricity utilities (ADB, 2013). In an attempt to reduce the losses, domestic prices have risen $81 \%$ in 4 years, an average of $16 \%$ per year, and in 2013/14 are Rs3.29/kWh (approximately 5.5c/kWh). Even with these sharp increases, the domestic retail tariff results in a loss of Rs4.56/kWh (approx. 7.6c/kWh) (Planning Commission, 2014a). Just to break even, the utilities need to increase domestic (and agricultural) retail tariffs by $139 \%$ to Rs7.85/kWh (approx. 13c/kWh). Table 2 provides the detail of electricity tariffs and the utilities' lack of profitability.

\subsection{Bihar's electrification options}

The Bihar Government thus faces a choice. Electrification of its people can be achieved through investment in coal-fired generation, transmission and distribution infrastructure that will have an operating life of $40-50$ years and the costs associated with large, long-lived investment. This will concentrate the business opportunity and economic benefit from the investment stimulus to the few, generally outside the state, who have the resources to finance very large investments. Alternatively, investment in small, distributed generation can be pursued by locally based electricians, operators and businessmen in increasing quantities of energy as the economy grows, demand increases, technologies evolve and skills are dispersed throughout the State.

Historically, electrification plans have considered distributed generation only in remote areas, with the major thrust for village electrification through large, centralised coal-fired generation transmitted to rural areas. These plans have been expensive and not highly successful (ADB, 2013). Recently, however, small commercial operations are engaging with rural communities to provide energy services utilising biomass, solar-photovoltaic (solarPV) and/or micro-grids requiring micropayments on a monthly or weekly basis (GNESD, 2014, Bhattacharyya and Palit, 2014, Krithika and Palit, 2013). Costs per kWh are higher than current tariffs, but the roll-out is quick, the technology is 
decreasing in cost, the infrastructure lock-in is likely to be 10 years rather than $40-50$ years, pollution and carbon emissions are significantly reduced and the economic stimulus is retained within the state.

\subsubsection{Investment in coal-fired generation, transmission and distribution}

\subsubsection{Potential demand}

In most research rural electrification is estimated on modest levels of demand, largely due to a lack of resources to pay for electrical devices or lavish electrical consumption. Researchers from the Ministry of New and Renewable Energy in India have quantified demand for a rural household as $0.675 \mathrm{~kW}$ (Nouni et al., 2009). Other studies point to levels of demand for lighting, fans and TV only of $0.2 \mathrm{~kW}$ (Bhattacharyya, 2015). From current data on domestic household consumption, electricity demand is estimated to be $0.367 / \mathrm{kW}$ (Planning Commission, 2014a), which indicates that affordability may set average demand at the lower level of demand. Electrification to a higher household demand of $0.675 \mathrm{~kW}$ gives the minimum capacity required for evening peak, of $12.8 \mathrm{GW}$. Applying the lower level of demand of $0.3 \mathrm{~kW}$ would extrapolate to a minimum capacity required for evening peak of 5.7GW. For the rest of the analysis, both the higher and lower levels of demand will be examined.

Bihar currently has $0.5 \mathrm{GW}$ installed, and access to $1.3 \mathrm{GW}$ of in-state but centrally controlled generation, with up to $2.7 \mathrm{GW}$ of planned generation allocated to Bihar over the next 2 years, making a total of $4.5 \mathrm{GW}$ of potential generation in the foreseeable future. The higher demand level would suggest a requirement for additional coal-fired generation of $12,290 \mathrm{MW}$ and the lower level would indicate $4,477 \mathrm{MW}$ of new coal-fired generations. Calculation details can be found in Table 3 .

\subsubsection{Fuel requirements}

India's inability to source coal from domestic sources has led to interest in the Galilee Basin in Australia. Assuming that the planned and un-met demand capacity is installed, and that the usual assumptions with respect to thermal efficiency are made, Bihar's coal fired power stations will 
require 31.9 million tonnes per annum (mtpa) of coal for the higher level of demand and 11.6mtpa for the lower level of demand as detailed in Table 3.

\subsubsection{Capital costs for transport infrastructure in India}

Existing power plants in Bihar and West Bengal have struggled to access capacity on the Indian rail network to transport their coal from the ports (Government of India, 2013b), especially in November to March when grain takes up much of the available capacity (IWAI, 2010). In 2013, NTPC started shipping coal to their West Bengal plant using barges from Sandheads in the Bay of Bengal, outside Kolkata port, up National Waterway 1 . The cost of the barges and the additional terminals for the transport of 3mtpa of coal were reported to be Rs5.76 billion (Government of India, 2013a). Without detailed analysis into the cost of infrastructure requirement to accommodate the greater levels of wharfage and transport of coal to Bihar it is not possible to posit a reasonable investment cost. However, if the investment in the barge system, extrapolated for the requirement for coal transportation, is used as a proxy for investment cost, then it is possible to have an indicative investment cost associated with the additional transport capacity. The costs are included in Table 5.

\subsubsection{Capital costs for coal-fired power stations}

The International Energy Agency (IEA) provides assumptions for the capital cost of investment in super-critical coal-fired power stations in India, at US\$1,200/kW (IEA, 2014d). Listed in the Bihar State Investment Promotion Board's (BSIPB) infrastructure approvals (Bihar Government, 2014) are 29 coal-fired power stations with a combined capacity of $40.9 \mathrm{GW}$ that have been proposed and approved since 2007 at an average (inflation adjusted) cost of US\$1,210/kW which supports the IEA assumptions. Notably only 2 of these proposals are in-state proposals from Bihar. The majority of proposals originate in Kolkata or New Delhi.

The investments required for the fleet of coal-fired power stations for both the higher and the lower level of demand are included in Table 3. With development banks and aid agencies stepping away from assistance for coal-fired generation (Yukhananov and Volcovici, 2013, Williams, 2014, Williams, 
2015) and the financial situation of the Bihar electricity utilities, financing for investment in coalfired generation would be a significant risk for investors and banks (Engelmeier et al., 2014a). For this reason, many of the projects identified in the BSIPB's approvals have not progressed, delaying indefinitely the State's ability to provide the generation capacity for rural electrification.

\subsubsection{Costs for transmission and distribution}

According to the Power System Master Plan for Bihar, to reach annual peak of 5.4GW (lower than the 5.7GW of lower demand assumption made here), Rs90 bn (approx. \$1.5bn) needs to be invested in transmission infrastructure over the period 2009 to 2018 and Rs37 bn (approx. $\$ 613,000$ ) over the period 2010 to 2014 for distribution infrastructure. If the higher level of demand was required, this level of investment would need to continue until the peak demand of $12.8 \mathrm{GW}$ was reached. Details are provided in Table 4.

\subsubsection{Total investment required for centralised generation and distribution to rural consumers}

Table 5 provides a summary of all the investment requirements for centralised generation and distribution in Bihar using coal sourced from mines to be developed in the Galilee Basin. The cost of the Galilee Basin mine and rail project capital investment after 20 years, is apportioned to Bihar according to the Bihar annual coal requirement as a percentage of full Carmichael Mine production capacity of $60 \mathrm{mtpa}$. The purchase and development cost of Abbot Point Coal Terminal is apportioned based on coal requirement as a percentage of full coal terminal throughput of $85 \mathrm{mtpa}$. Thus over a 20 year period of the electrification project, more than \$26 billion will be invested in new infrastructure. For the lower demand option, the investment required is for $\$ 9.6$ billion.

\subsubsection{Other costs of coal-fired generation}

\section{Water use}

Assuming the usage of the NTPC power plants recently commissioned, water requirements for every 1000MW equate to 38million cubic meters per year (Bihar State Power Holding Company, 2015). 
Therefore $12.3 \mathrm{GW}$ of generation would require approximately 467 million cubic meters of water per year. The lower demand requirement of 4.5GW of generation would use approximately 171 million cubic meters of water per year. Without data on the economic value of water in Bihar, the economic cost associated with water use has not been included in the analysis.

\section{Carbon emissions over the life-time of the plants}

Carbon emissions can be calculated as per Australia's National Greenhouse Accounts Factors (Australian Government, 2014).

Estimating the costs of $\mathrm{CO}_{2}$ emissions is challenging because of the varying levels of control measures that exist around the world. Here India's coal tax of Rs 100/t of coal is applied, in effect it is a carbon tax of $\$ 0.86 / \mathrm{tCO}_{2}{ }^{\mathrm{e}}$, which is used to fund renewable energy projects. Further details are provided in Table 6.

\section{Other pollutants emitted from the plants}

Nitrogen oxide $\left(\mathrm{NO}_{\mathrm{x}}\right)$, sulphur dioxide $\left(\mathrm{SO}_{2}\right)$ and particulate matter form when fuel is burned at high temperatures and are indicated with respiratory problems. Adani does not provide details of the sulphur and nitrogen content of the Carmichael Mine coal. However, the physical and chemical properties of Kevin's Corner and Alpha Coal (two mines also in the Galilee Basin) point to the same level of nitrogen content as Curragh coal mine which supplies Stanwell coal fired power station, and the same level of sulphur content as Kogan Creek coal mine which supplies the Kogan Creek coal fired power station (Bureau of Mining and Petroleum, 2003). Using the emissions levels from these power stations provides an estimate of the level of emissions likely from power stations burning Galilee Basin coal. Details of emissions can be found in Table 7.

If the $\mathrm{NO}_{\mathrm{x}}$ emissions calculated for Bihar's higher demand are aggregated across landmass, Bihar power stations will have emissions at $70 \%$ of the level of that of China's. Bihar's $\mathrm{SO}_{2}$ emissions will be at the same level as China's. Bihar's emissions for the higher demand estimation will be associated with average electricity consumption of just over $840 \mathrm{kWh} /$ person/year which is less than a quarter 
of the electricity consumption of China. If Bihar were to continue to use coal for increasing levels of electricity consumption, the pollution problem would become more acute than China's.

In an attempt to reduce its pollution levels, China is budgeting \$278 billion over a five year period to control pollution. Measures to reduce pollution include the control of emissions of $\mathrm{SO}_{2}, \mathrm{NO}_{x}$ and particulates through investment in pollution control technology; caps on consumption of coal for power generation; and the transition away from old coal boilers to either gas or renewable energy (Ministry of Environmental Protection, 2013, IGES, 2013). To calculate the potential pollution control cost for Bihar, China's pollution related expenditure of $\$ 278$ billion is apportioned per kW of coalfired generation capacity and then applied to the installed base of coal-fired generation in Bihar. Details are provided in Table 7.

China estimates that air quality improvement will have a social benefit of $\$ 320$ trillion (IGES, 2013). Other research has shown that pollution has created a drag on the Chinese economy of between 5 and $14 \%$ (Matus et al., 2012) which includes welfare loss associated with mortality (72\% of welfare loss) and health, productivity loss and lost leisure costs associated with ill-health ( $28 \%$ of welfare loss). From this analysis health, productivity loss and lost leisure costs would equate to $1.7 \%$ of GDP. Bihar's economy is projected to continue to grow at $10 \%$ over the next 10 years with the annual health costs excluding mortality on Bihar's GDP capped at $1.7 \%$ of GDP in 2019. Calculation assumptions are included in Table 7.

\section{Premature deaths as a result of air pollution}

Burning coal in high population-density areas increases risk for local populations. Bihar has a population density of 1,105/sq.km. By comparison, China has a population density of 142/sq.km, with Guangdong province which has a comparable population size to Bihar having a population density of 589/sq.km. Hebei province, which is infamous for having some of the worst polluted cities in China, has a population density of $387 / \mathrm{sq} \cdot \mathrm{km}$. 
If the same proportion of the population in Bihar is statistically likely to experience premature death as is being experienced in China, then between 27,000 and 39,000 people per year in Bihar will die prematurely as a result of air pollution. Estimates of the value of human life in India produce highly varied results. (Simon et al., 1999) valued life in India at between Rs6.4-15.0 million. (Shanmugam, 2000) valued life in Tamilnadu at Rs $13.78-18.55$ million. (Madheswaran, 2007) valued life in Mumbai at Rs14.8 million. (Mahapatra et al., 2012) in their analysis of the external costs of coal fired generation in Ahmedabad, used a 1994 valuation adjusted for inflation to 2005, of Rs798000 (\$13300). A report from (WorldBank, 2013) used a combination of sources and models to reach an estimation of the cost of adult mortality of Rs 9.1 million. The Ahmedabad analysis would appear to be out of step with the other analyses, so in line with the lowest of the remaining estimations (the World Bank report), Rs9 million (\$150000) per life is assumed which extrapolates to Rs297 billion (US\$4.95bn) per year.

\subsubsection{Benefits of centralised generation and distribution to rural} consumers

The 29 coal-fired power projects approved by the BSIPB indicate employment opportunities of around 22,000. Applying the average employment included in the proposals to power stations required to meet rural electrification demand, indicates employment potential for 6,670 individuals and at the lower demand, employment potential could be 2,430. Details are provided in Table 8.

\subsubsection{Investment in renewable energy systems and village micro-grids}

Biomass and small hydro systems have always been available to remote communities as sources of electrification, so India's Ministry of New and Renewable Energy has long proposed the deployment of small renewable energy configurations to rural locations. However, with the attention and funding given to the electrification of $100 \%$ of villages program through transmission and distribution investment, the roll-out of distributed electrification has been limited. As solarPV costs 
started reducing, solarPV proposals to the BSIPB increased with a total of 47 proposals received since 2009 proposing $1.5 \mathrm{GW}$ of solarPV installations.

Electrification in Bangladesh provides a comparison to the Indian centralised model. Solar Home Systems (SHS) and micro-finance in Bangladesh has led to the roll-out of around 3 million SHS since 2003 and the creation of 114,000 jobs in the renewable energy sector (IRENA, 2014), including the manufacture of all the componentry for the SHS within Bangladesh (Sadeque et al., 2014).

China, having achieved close to its $100 \%$ electrification objective, also provides an example of successful electrification programs for remote communities using decentralised power systems. China encouraged small local renewable and fossil fuel electrification systems that were developed and managed by the local community but with funding and support from central and local governments. This resulted in rural development, rural capacity building, and the deployment of decentralised options based on the natural resources available to the rural community. Local involvement ensured greater levels of local participation and income creation (Bhattacharyya and Ohiare, 2012).

\subsubsection{Understanding the capacity requirement and the cost}

As mentioned earlier, capacity requirements tend to vary but are limited by what consumers can afford. (Nouni et al., 2009) suggest a household demand of $0.675 \mathrm{~kW}$ whilst others like (Bhattacharyya, 2006) have estimated village demand to average around $0.222 \mathrm{~kW}$ per household including electricity for commercial and agricultural purposes. Research conducted in Assam, India by (Chattopadhyay and Bose, 2012), in a similar geography to Bihar, provides data on villages with an average demand of $0.3 \mathrm{~kW}$. Assumptions included in Rajasthan's 24x7 Energy For All proposal assumes an average demand of $0.3 \mathrm{~kW}$ per household (Government of Rajasthan, 2014). The current average household consumption in Bihar for additions over the last 3 years which perhaps best represents the recent addition of rural households, would appear to be around $0.367 \mathrm{~kW}$ (Planning 
Commission, 2014a). For this reason, $0.3 \mathrm{~kW}$ per household is included as the minimum, initial, requirement for household electrification.

With solarPV costs decreasing fast, it is difficult to find research which provides current estimates of decentralised renewable energy systems, but there are some relevant studies which are detailed below.

Analysis of village level off-grid systems in Bangladesh used solarPV costs of $\$ 2,800 / \mathrm{kW}$, $\$ 150 /$ battery $(6 \mathrm{~V})$ and inverter costs of $\$ 200 / \mathrm{kW}$ and found that hybrid models of diesel generators and solarPV panels with a mini grid have a LCOE of $\$ 0.34-0.37 / \mathrm{kWh}$ (Bhattacharyya, 2015).

Research into the benefits of using solarPV in Bihar to counteract power shortages as a result of supply-demand imbalances of between two and nine hours a day, show that the cost of energy from solarPV panels in the urban setting of Patna is Rs 11.9/kWh (20c/kWh) (Engelmeier et al., 2014a). Another report found that large rooftop solarPV systems of 10-500kW, with low transmission infrastructure investment, in 2015 have a capital cost of $\$ 1,333 / \mathrm{kW}$ and delivered power cost of Rs9.7/kWh (16c/kWh) (Engelmeier et al., 2014b).

Rural electrification is a part of the Government of Rajasthan's proposal for 24x7-Power For All programme proposal. Included in their proposal for rural electrification are single household systems or very small village off-grid solarPV-battery micro-grid options where capital costs are not itemised but the LCOE would equate to Rs 38-44/kWh (\$0.63-0.74/kWh) (Government of Rajasthan, 2014).

Findings in rural Assam, a North East State in India, indicate that customising local resources including biomass, micro-hydro and solarPV reduces the requirement for storage and the delivered cost of energy (Chattopadhyay and Bose, 2012) for villages with 250-300 households and demand of $0.3 \mathrm{~kW}$ per household. This research also found that these systems could easily be connected to the grid in the future providing benefit both to the grid and the village at little extra cost. 
(Greenpeace India, 2012) conducted a bottoms-up calculation of micro-grid electrification of Bihar in 2012, and based on 2011 costs found the overall cost of electrification for Bihar to be Rs11-13/kWh (US\$18-21c/kWh) using solarPV, battery, biomass, hydro and micro-grids.

Realistically solarPV costs will be higher in rural areas, but if there is to be a large-scale roll-out of decentralised systems to Bihar, then costs could be similar to those included in the large-scale solarPV implementation report (Engelmeier et al., 2014b). With the announcement of Adani's Joint Venture with SunEdison to manufacture low-cost solarPV panels for domestic consumption (Economic Times, 2015), competition between solarPV manufacturers will place downward pressure on Indian manufactured solarPV module prices.

\subsubsection{Extrapolating capital costs for Bihar}

In the absence of a detailed study into each village's resources and requirements, a high level extrapolation of village electrification costs is detailed here. Using the (Chattopadhyay and Bose, 2012) research as a framework, and estimating an average of 250 households per village, theoretically 63,337 village installations are required (in reality village sizes vary greatly, as there are a total of 39,015 villages, but for the purposes of this high level assessment and the application of benchmark installations, the theoretical village size is applied to avoid scaling error). Not all villages need be reliant on only solarPV systems because biomass and hydro opportunities are also available (MNRE and IISc, 2004). Applying capacity and cost assumptions included in (Chattopadhyay and Bose, 2012), but adjusting for lower solarPV panel costs as included in (Engelmeier et al., 2014b) provides a current cost per village implementation.

Table 9 provides the detail of calculations involved in estimating the capital costs for using Bihar's natural resources for rural electrification. The total capital cost utilising solarPV-battery micro-grids, biomass and micro-hydro potential would amount to Rs725 billion (\$12.1 bn). This is the investment requirement for 10 years or Version 1 of the decentralised renewable systems because batteries and inverters have approximately 10 year lifespans before requiring upgrade. 
The IEA predicts that solarPV will have modest decreases in panel prices over the next 10-20 years but proposes that there is potential for significant decreases in storage costs over the next $10-20$ years (IEA, 2014a, IEA, 2014b), which supports expectations that by 2025 the investment cost for decentralised solarPV-battery systems will halve (Fraunhofer ISE, 2015). For this reason, it is suggested here, that the second round of decentralised renewable systems, Version 2, will enable the upgrade of the village systems with solarPV installations to double capacity at the same price as Version 1.

Thus villagers will have access to a lower level of electrification for 10 years but will be able to upgrade to the higher level of demand as the componentry of the village systems requires replacement, at the same cost or less than the original investment.

It is this property of scalability that makes the decentralised village-based systems attractive for rural electrification. Modest levels of demand can be addressed with small modular systems, which can be upgraded when demand and affordability allow.

\subsubsection{Extrapolating rural development benefits from rural electrification program}

Every village will require local people to implement, operate and manage each of these small microgrids. There are a few potential sources for estimating the employment opportunities:

- Investment proposals which indicate potential employment of 23,000 for $1.5 \mathrm{GW}$ of solarPV for Bihar (Bihar Government, 2014). Apportioning employment opportunities for 5.2GW of electrification infrastructure can be extrapolated to 79,110 ; or

- The proposal for the management of the Dharnai village decentralised system which indicates that a local technician is required to: monitor the system on a daily basis; set up new connections (e.g. wiring, installing meters); provide the first level of support for technical problems; and conduct minor repair and maintenance work. A further resource will be required to enrol new users, track usage, calculate billing and collect fees on a regular 
basis (Greenpeace India, 2014). This could equate to 2 persons per 450 household village or a total of 70,375 persons for $15,834,366$ households across Bihar; or

- Using Bangladesh's SHS proposal as an indication of rural development potential with the establishment of 114,000 jobs for the electrification of 3 million households. This would equate to approximately 600,000 jobs but without existing manufacturing capacity in Bihar, it is unlikely that Bihar will be able to upskill to this level in the required period, but other states in India could.

The first 2 estimations indicate potential employment for 70,000-80,000 individuals to earn an income from rural electrification utilising the local renewable resources. The third estimation promises significant upside potential for Bihar and Indian employment. This employment potential would be ongoing as higher levels of capacity are rolled out in subsequent upgrades to new versions of the decentralised model.

In order to calculate the benefit in terms of the investment, it is suggested that income potential from employment can be calculated as average GDP/adult. This average income estimation can be applied to employment potential as indicated in Table 10.

\section{RESULTS}

\subsection{Investment requirements to meet demand}

Table 11 provides the all-up investment cost comparison for the higher demand level with the assumption that each rural implementation will be able to upgrade and double the size of the implementation at the same cost as the first version. The higher demand level is chosen for comparison to allow for residential demand growth.

Centralised provision of electricity requires $\$ 26.6$ billion of investment (and associated financing costs) in mining, transport, generation and network infrastructure. By comparison, Version 1 and 2 of the decentralised generation option requires \$27 billion of investment in micro-generation 
infrastructure. Centralised provision of power incurs mortality, health and pollution control costs of $\$ 70.7$ billion. Once the costs of mortality, health and pollution control are added, the cost of the coal option becomes more than triple the cost of the decentralised option.

\subsection{Levelised cost analysis}

LCOE are estimated based on investment requirements, variable operating costs, financing charges and energy consumption. The different elements of LCOE are calculated as detailed in the next subsections.

\subsubsection{Cost of coal from the Galilee Basin}

The Adani Carmichael Coal Mine Economic Assessment claims that the production cost of coal from the Carmichael Mine will be around AU\$33/tonne of coal over the life of the project (GHD Pty Ltd, 2013). However to the production cost needs to be added financing, overheads, royalties, rail and port costs before it can be exported from Australia. Analysis of the project concludes that the marginal cost of coal, free on board, equates to $\$ A U 73 /$ tonne, an estimation that is supported by the analysis of (Buckley and Sanzillo, 2013) although it is lower than other analysts' estimations (Paul and Wilkes, 2014).

Thereafter the coal needs to be transported to Paradip, a deep water port, on the East Coast of India. A global oversupply of coal has caused miners in Australia to reduce production (Janda, 2014, Hume, 2015), with a consequential fall in coal freight rates from higher than $\$ 16 / t$ at the beginning of 2014 (Ker, 2014) to approximately $\$ 9 / t$ at the beginning of 2015. If however, large volumes were being exported from the Galilee Basin, it is likely that freight rates would recover. For this reason transport rates from the East Coast of Australia to the East coast of India in the mid-point of the highs and lows of last year, at $\$$ US13.50/t (ArgusMedia, 2014) are used. Once in Paradip, the coal would need to be transported approximately $850 \mathrm{~km}$ by rail to the state of Bihar. Rates for port charges and rail transportation to Bihar are calculated at Rs1287/t or \$21.4/t (Indian Railways, 2014, Gazette of India, 2011). 
The cost of coal delivered to the power station would therefore be US\$94/t with detail provided in Table 12. To this might be added, the cost of fly ash disposal, which currently is transported down the Ganges River to National Waterway 1 and shipped to Bangladesh. There are however proposals to use the ash to manufacture bricks which could eliminate this cost (Bihar Government, 2014), so it is not included as an additional cost associated with burning coal.

\subsubsection{Cost of electricity from coal-fired generation}

The LCOE associated with electricity generated using coal sourced from the Galilee Basin is estimated to be $\$ 0.084 / \mathrm{kWh}$, based on the assumptions detailed in section 2 .

\subsubsection{Network costs to distribute electricity from coal-fired power stations}

Breakdowns in the cost of electricity provided by the Planning Commission do not provide separate costs for transmission and distribution. With the rural electrification program generally funded by grants or low-interest loans from the Government of India (Bhattacharyya, 2006, Niez, 2010), it appears that the local network costs are included in tariffs as staff/admin/overhead costs, depreciation and interest charges. If the non-power purchase costs are estimated to be the cost of electricity distribution, then the current cost of distributing power in Bihar is calculated to be Rs1.59/kWh (approx. \$0.027/kWh) (Planning Commission, 2014a). This cost may decrease per kWh as consumption increases, but there will be increased costs associated with new customers, so it is assumed that it remains a baseline for distribution cost into the future.

Combining the existing distribution costs with the apportionment of the investment costs and the cost of network losses of $20 \%$ provides a transmission and distribution cost of Rs 3.09/kWh (approx. $\$ 0.052 / \mathrm{kWh})$. Details are provided in Table 13. 


\subsubsection{Levelised cost of village level decentralised electrification}

Using the investment costs as detailed above, and applying operating costs as detailed in (Chattopadhyay and Bose, 2012, IRENA, 2012a, IRENA, 2012b), allows a comparable LCOE of Rs8.10 $(\$ 0.135 / \mathrm{kWh})$ for the village level decentralised model as detailed in Table 14.

\subsection{Levelised cost comparison}

Centralised provision of electricity from coal equates to a cost of $13.5 \mathrm{c} / \mathrm{kWh}$ compared to $13.5 \mathrm{c} / \mathrm{kWh}$ for decentralised electricity, as detailed in Table 15. Network losses for the provision of power from central sources are assumed to be $20 \%$ of energy sent out, which is considerably lower than current losses. This suggests that $13.5 \mathrm{c} / \mathrm{kWh}$ could be understated.

When the welfare costs per kWh consumed from coal generation are added to the LCOE comparison, the cost of electricity from coal-fired generation becomes $24 \mathrm{c} / \mathrm{kWh}$ which is significantly higher than the decentralised option.

\section{DISCUSSION}

High levels of outages, theft, demand-supply imbalance, financial problems for state electricity utilities, and a high proportion of households still without access to electricity are the result of an electrification policy with a focus on a singular solution. It is widely considered that this policy has been ineffectual despite significant investment (Chattopadhyay, 2013). The financial scale and industrial consumption required for large coal-fired generation has hampered the process of electrification to all.

Developing mines and rail-links in the Galilee Basin and building power stations and network infrastructure to meet demand in Bihar will require \$26.6 billion of investment in 3 international projects and approximately 15 domestic projects. By comparison, the decentralised option requires $\$ 27 \mathrm{bn}$ of investment in 2 phases of thousands of projects. The decentralised option provides 
consumers with a lower potential for consumption for the first 10 years, but they benefit from the increase in technological capability after waiting 10 years.

Decentralised investments implemented in stages and upgraded as technology advances, allow for smaller absolute investment and financing required for shorter periods of time. The risks of the investment in decentralised systems are spread over a wider base reducing the overall risk profile. The decentralised model encourages rural development through local investment and employment as opposed to the centralised model which concentrates financial returns and employment benefits in urban centres and other states and countries.

The LCOE of centralised power is approximately the same as the decentralised option if the externalities are specifically excluded. However centralised generation, at $67 \%$ capacity factor, assumes the generation of a larger amount of energy than does the decentralised option. This larger amount of energy is predicated on 2 assumptions. Firstly, rural consumers will be able to afford the higher levels of demand, and secondly industry consumption will grow significantly in Bihar. In the model as calculated $12.3 \mathrm{GW}$ of coal-fired plant can be expected to generate $72 \mathrm{TWh}$. However, the 12.3GW capacity requirement has been based on residential demand only, and will generally only be drawn down for 4-6 hours at night. Thus at the higher level of demand only 20TWh per annum will be consumed by residential customers. At an optimistic network loss of $20 \%$ a further 14 TWh will be lost in distribution, leaving 38TWh of energy in search of industrial consumers. Currently, Bihar's non-domestic consumption is 6TWh and from that level is expected to rise to 10TWh over a 5 year period (12TWh under an optimistic scenario)(SNC-Lavalin, 2010).

Figure 1 illustrates the challenge for base-load generation in Bihar. The area under a preferred coalfired power supply curve but above the Bihar consumption load curve is unlikely to be required or billable. Plants will generate electricity according to the Bihar consumption curve, which is not commercially or technically advisable. 
The centralised electricity model has been developed to rely on industry consumption to underpin residential aspirations. Globally, $27 \%$ of all electricity is consumed by residential users. However, in China residential users consume only $15 \%$ of all electricity whilst in the USA residential users consume $37 \%$ of all electricity. Without unprecedented growth in industry demand, Bihar's residential consumption would be $66 \%$ of total consumption. Bihar is actively pursuing industry relating to its agricultural base, but the proposals currently under consideration are unlikely to provide the industrial demand to shoulder the capacity required for the rural consumers. Using projections of non-domestic consumption and adding the domestic consumption and network losses to power all households, point to a capacity factor of $36 \%$ for the coal-fired fleet. Power stations could try to sell their excess supply outside of Bihar but the surrounding states are facing the same demand profile. The people of Bihar, therefore, are likely to have to wait for industrial consumption to grow before electrification can be made available through the centralised option. For now, their best chance of electrification is to start small with decentralised, renewable energy micro-grids and then upgrade as technology matures.

\section{CONCLUSION AND POLICY IMPLICATIONS}

Coal has been the preferred fuel for stationary energy for more than 100 years. Its history tells a story of a major contribution to development but also to ill-health since the industrial revolution. Its legacy is that it has contributed to the stock of carbon dioxide in the atmosphere that now threatens the stable climate that has underpinned global economic growth. The cost of coal lies not only in extracting and transporting it to demand centres, but also in the cost to current and future populations.

This paper finds that using coal to provide electrification to densely populated Bihar will require high levels of investment and finance, and incur mortality and health costs from pollution. Providing electricity from a staged introduction of local renewable energies would be preferable. The roll out of small, decentralised renewable energy systems to villages in rural India will provide greater 
benefit to the villagers through the potential for business and employment from a large rural development stimulus program. This leapfrog of traditional electricity generation technology to emergent renewable technologies has significant policy implications for the Indian government. Investment in rural network infrastructure, large coal-fired power stations and risky mining ventures, can be directed instead toward local, decentralised village programs. Research elsewhere has been conducted into business models for development and operation of decentralised village programs but how these programs could deliver on the scale required is an area that needs research.

\section{REFERENCES}

ACIL TASMAN 2009. Fuel resource, new entry and generation costs in the NEM: Final Report 9. Report prepared by ACIL Tasman for the Interregional Planning Committee (IRPC).

ADB 2013. Sector assessment (summary): Energy. Country Partnership Strategy:India. Manila, Phillipines: Asian Development Bank.

ARGUSMEDIA. 2014. Argus Coal Daily International [Online]. London: ArgusMedia. Available: http://www.argusmedia.com/ /media/Files/PDFs/Samples/Argus-Coal-DailyInternational.pdf?la=en.

AURIZON 2014. Annual Report. Brisbane, Australia.

AUSTRALIAN GOVERNMENT 2013. National Pollutant Inventory. Canberra: Department of Environment.

AUSTRALIAN GOVERNMENT 2014. National Greenhouse Accounts Factors. Canberra, Australia: Department of Environment.

BHATTACHARYYA, S. C. 2006. Energy access problem of the poor in India: Is rural electrification a remedy? Energy Policy, 34, 3387-3397.

BHATTACHARYYA, S. C. 2015. Mini-grid based electrification in Bangladesh: Technical configuration and business analysis. Renewable Energy, 75, 745-761.

BHATTACHARYYA, S. C. \& OHIARE, S. 2012. The Chinese electricity access model for rural electrification: Approach, experience and lessons for others. Energy Policy, 49, 676-687.

BHATTACHARYYA, S. C. \& PALIT, D. 2014. Mini-grids for rural electrification of developing countries analysis and case studies from South Asia. Springer.

BIHAR GOVERNMENT 2014. Proposals Approved by State Investment Promotion Board (SIPB) Patna, Bihar, India: Bihar Government.

BIHAR STATE POWER COMPANY 2012. Business Plan for Bihar State Power Transmission Company for control period from FY 2013-14 to FY 2015-16. Bihar: Bihar State Power (Holding) Company.

BIHAR STATE POWER HOLDING COMPANY. 2015. New Power Projects [Online]. Patna, India: Bihar Government. Available: http://bsphcl.bih.nic.in/B-Projects.htm [Accessed 24/02/2015 2015].

BLOOMBERG. 2015a. Australian Government Bond Yields [Online]. New York: Bloomberg. Available: http://www.bloomberg.com/markets/rates-bonds/government-bonds/australia/ [Accessed 10 April 2015. 
BLOOMBERG. 2015b. Indian Government Bond Analysis [Online]. New York: Bloomberg. Available: http://www.bloomberg.com/quote/GIND10YR:IND [Accessed 10 April 2015.

BUCKLEY, T. \& SANZILLO, T. 2013. Remote Prospects: A financial analysis of Adani's coal gamble in Australia's Galilee Basin. Cleveland, Ohio, USA: The Institute for Energy Economics and Financial Analysis.

BUREAU OF MINING AND PETROLEUM 2003. Queensland coals: Physical and Chemical Properties, Colliery and Company Information. 14th ed. Brisbane: Department of Natural Resources and Mines.

CHATTOPADHYAY, D. 2013. Electrification of Remote Villages in Assam (India): Issues and Case Studies. Power and Energy Society General Meeting (PES), 2013 IEEE. Vancouver, B.C.: IEEE.

CHATTOPADHYAY, D. \& BOSE, S. 2012. Assessment of Renewable Opportunities in off-grid Locations in Assam. Asian Development Bank.

CHEN, Z., WANG, J.-N., MA, G.-X. \& ZHANG, Y.-S. China tackles the health effects of air pollution. The Lancet, 382, 1959-1960.

CHOUDHARY, K. \& CHOUDHARY, S. 2010. Testing capital asset pricing model: empirical evidences from Indian equity market. Eurasian Journal of Business and Economics, 127-138.

CS ENERGY 2013. Statement of Corporate Intent. Brisbane, Australia: CS Energy.

DAMODARAN, A. 2013. Equity risk premiums (ERP): Determinants, estimation and implications-The 2013 edition. New York University.

DAMODARAN, A. 2015. Equity Risk Premiums (ERP): Determinants, Estimation and Implications The 2015 Edition. New York: New York University.

ECONOMIC TIMES. 2015. Vibrant Gujarat Summit: Adani Enterprises, SunEdison to invest Rs 25,000 crore in Gujarat. The Economic Times.

ENGELMEIER, T., KHURANA, J., GOEL, P., CHAUDRI, K. R., JAIN, M., LOOND, T. \& JYOTI, A. 2014a. Rooftop Revolution: Uncovering Patna's Solar Potential. New Delhi: Bridge to India.

ENGELMEIER, T., RUSTAGI, V., KHURANA, J., GOEL, P., CHAUDRI, K. R. \& JAIN, M. 2014b. Beehives or elephants? How should India drive its solar transformation? New Delhi: Tata Solar Power, Bridge to India.

FOSTER, J., WAGNER, L. \& BRATANOVA, A. 2014. LCOE models: A comparison of the theoretical frameworks and key assumptions. Brisbane, Australia: University of Queensland, Australia.

FRAUNHOFER ISE 2015. Current and Future Cost of Photovoltaics: Long-term Scenarios for Market Development, System Prices and LCOE of Utility-Scale PV Systems. Agora Energiewende.

FREESE, B. 2006. Coal: A human history, London, Arrow Books.

GAZETTE OF INDIA 2011. Tariff Authority for Major Ports: Paradip Port Trust. New Delhi, India: Government of India,.

GHD PTY LTD 2013. Report for Economic Assessment. Carmichael Coal Mine and Rail Project SEIS. Brisbane, Australia: Adani Mining Pty Ltd.

GNESD 2014. Renewable energy-based rural electrification: The Mini-Grid Experience from India. New Delhi: The Energy and Resources Institute.

GOVERNMENT OF INDIA 2013a. Shipping Minister Launched Inland Waterways Projects at Kolkatta. In: SHIPPING, M. O. (ed.). New Delhi: Government of India.

GOVERNMENT OF INDIA 2013b. Thermal power plant coal supply to improve with expansion of inland water transport mode. Kolkata: Press Information Bureau,.

GOVERNMENT OF INDIA 2014. Renewable Energy Programmes Gets A New Impetus; Focus on Development of Energy Infrastructure. In: MINISTRY OF NEW AND RENEWABLE ENERGY (ed.). New Delhi: Government of India,.

GOVERNMENT OF RAJASTHAN 2014. 24x7-Power For All. Government of Rajasthan.

GREENPEACE INDIA 2012. "e[r] cluster" for a smart energy access: The role of Microgrids in promoting the integration of Renewable Energy in India. Bangalore, India: Greenpeace.

GREENPEACE INDIA 2014. Dharnai Live Microgrid Media Manual. New Delhi: Greenpeace India.

HUME, N. 2015. Glencore's thermal coal output cut set to warm market. Financial Times. 
IEA 2014a. Technology Roadmap: Energy Storage. Energy Technology Perspectives. Paris: International Energy Agency.

IEA 2014b. Technology Roadmap: Solar Photovoltaic Energy. Energy Technology Perspectives. Paris: International Energy Agency.

IEA 2014c. World Energy Outlook. Paris: International Energy Agency.

IEA 2014d. World Energy Outlook 2014 Power Generation Investment Assumptions. Paris: International Energy Agency.

IEA 2015. World Energy Balances. In: AGENCY, I. E. (ed.). Paris: International Energy Agency.

IGES 2013. Major Developments in Chinas National Air Pollution Policies in the Early 12th Five-Year Plan. Kanagawa, Japan: Institute of Global Environmental Strategies.

INDIAN RAILWAYS. 2014. Adjustments in base rates effective from 20.05.2014 [Online]. New Delhi, India: Government of India,. Available: http://www.indianrailways.gov.in/railwayboard/uploads/directorate/traffic comm/Freight Rate 2K14/RC 15 14.pdf [Accessed 02/03/2015.

INDIAN RAILWAYS. 2015. Freight Operations Information System [Online]. New Delhi, India: Government of India. Available: http://www.fois.indianrail.gov.in/ [Accessed 4/03/2015.

IRENA 2012a. Biomass for Power Generation. RENEWABLE ENERGY TECHNOLOGIES: COST ANALYSIS SERIES. Masdar: International Renewable Energy Agency,.

IRENA 2012b. Hydropower. RENEWABLE ENERGY TECHNOLOGIES: COST ANALYSIS SERIES. Masdar: International Renewable Energy Agency,.

IRENA 2014. Renewable Energy and Jobs 2014. Abu Dhabi, UAE: International Renewable Energy Agency.

IWAI 2010. Coal movement on the Ganga: NW1. In: MINISTRY OF SHIPPING (ed.). Noida, U.P., India: Government of India,.

JANDA, M. 2014. Glencore shuts down Australian coal mines for Christmas [Online]. Ultimo, New South Wales, Australis: Australian Broadcasting Corporation. Available: http://www.abc.net.au/news/2014-11-14/glencore-shuts-down-australian-coal-mines-forchristmas/5890818 [Accessed 14/11/2014.

KER, P. 2014. Australian coalminers returning to profitability, but for how long? Sydney Morning Herald.

KPMG. 2015. Corporate tax rates table [Online]. Amsterdam, The Netherlands: KPMG. Available: http://www.kpmg.com/global/en/services/tax/tax-tools-and-resources/pages/corporatetax-rates-table.aspx [Accessed 2/03/2015.

KRITHIKA, P. R. \& PALIT, D. 2013. Participatory Business Models for Off-Grid Electrification. In: BHATTACHARYYA, S. C. (ed.) Rural Electrification through Decentralised Off-grid Systems in Developing Countries. London: Springer.

MADHESWARAN, S. 2007. Measuring the value of statistical life: estimating compensating wage differentials among workers in India. Social Indicators Research, 84, 83-96.

MAHAPATRA, D., SHUKLA, P. \& DHAR, S. 2012. External cost of coal based electricity generation: A tale of Ahmedabad city. Energy Policy, 49, 253-265.

MATUS, K., NAM, K.-M., SELIN, N. E., LAMSAL, L. N., REILLY, J. M. \& PALTSEV, S. 2012. Health damages from air pollution in China. Global Environmental Change, 22, 55-66.

METOFFICE. 2015. The Great Smog of 1952 [Online]. London: UK Government. Available: http://www.metoffice.gov.uk/education/teens/case-studies/great-smog [Accessed 5/02/2015 2015].

MINISTRY OF ENVIRONMENTAL PROTECTION. 2013. The State Council issues Action Plan on Prevention and Control of Air Pollution Introducing Ten Measures to Improve Air Quality [Online]. Beijing, China: Ministry of Environmental Protection. Available: http://english.mep.gov.cn/News service/infocus/201309/t20130924 260707.htm

[Accessed 23/02/2015 2015]. 
MNRE 2015. Small Hydro Programme (up to 25MW) - for the year 2014-15 and remaining period of 12th plan. New Delhi: Ministry of New and Renewable Energy.

MNRE \& IISC. 2004. National Biomass Resource Atlas V2.0 [Online]. Bangalore, India: Ministry of New and Renewable Energy. Available: http://lab.cgpl.iisc.ernet.in/atlas/Default.aspx [Accessed 16 February 2015 2015].

NATIONAL BUREAU OF STATISTICS OF CHINA 2013. China Statistical Yearbook. Beijing: Government of China.

NIEZ, A. 2010. Comparative study on rural electrification policies in emerging economies: Keys to successful policies. Paris: IEA.

NOUNI, M. R., MULLICK, S. C. \& KANDPAL, T. C. 2009. Providing electricity access to remote areas in India: Niche areas for decentralized electricity supply. Renewable Energy, 34, 430-434.

ODA, H. \& TSUJITA, Y. 2014. Rural Electrification in Bihar: Progress and Ground Realities [Online]. Chiba, Japan: Institute of Development Economies - Japan External Trade Organization. Available: $\quad$ http://www.ide.go.jp/English/Publish/Download/Report/2013/2013 C04.html [Accessed 5 February 2015 2015].

PAUL, S. \& WILKES, T. 2014. Adani steps up Australia coal plan ahead of Modi visit. Reuters, 12 November 2014.

PEABODY ENERGY. 2015. Peabody Energy Honored For Leadership Advancing Sustainable Energy Solutions At 5th World PetroCoal Congress [Online]. St Louis, Missouri: Peaboy Energy,. Available: $\quad$ http://www.peabodyenergy.com/Investor-News-Release-Details.aspx?nr=874 [Accessed 4/03/2015.

PLANNING COMMISSION 2014a. Annual Report on the Working of State Power Utilities and Electricity Departments (2013-14). New Delhi, India: Planning Commission.

PLANNING COMMISSION 2014b. Data-book compiled for use of Planning Commission. New Delhi, India: Government of India.

QUEENSLAND COMPETITION AUTHORITY. 2013. Weighted Average Cost of Capital Forum: Aurizon Rail [Online]. Brisbane, Australia: Queensland Competition Authority,. Available: http://www.qca.org.au/Rail/Aurizon/Intro-to-Aurizon/2013-Draft-Access-Undertaking/Ti/InProgress/Cost-of-Capital [Accessed 10 April 2015.

QUEENSLAND GOVERNMENT 2011. Premium price for Abbot Point Coal Terminal boosts disaster recovery. In: DEPARTMENT OF THE PREMIER AND CABINET (ed.). Brisbane: Queensland Government,.

S\&P. 2015. Standard and Poor's Ratings Services [Online]. New York: S\&P. Available: https://www.spratings.com/governments [Accessed 10 April 2015.

SADEQUE, Z., RYSANKOVA, D., ELAHI, R. \& SONI, R. 2014. Scaling up Access to Electricity: The Case of Bangladesh. LiveWire, 2014.

SHANMUGAM, K. R. 2000. Valuations of life and injury risks: Empirical evidence from India. Environmental and Resource Economics, 16, 379-389.

SIMON, N. B., CROPPER, M. L., ALBERINI, A. \& ARORA, S. 1999. Valuing Mortality Reductions in India: A Study of Compensating Wage Differentials. Washington, DC: WorldBank.

SIMSHAUSER, P. \& WILD, P. 2009. THE WESTERN AUSTRALIAN POWER DILEMMA. Australian Economic Papers, 48.4, 342-369.

SNC-LAVALIN 2010. Developing the power system master plan for Bihar. Asian Development Bank.

STANWELL CORPORATION 2013. Annual Report. Brisbane, Australia: Stanwell Corporation.

SVEC, V. 2014. Carbon tax must go: solution to energy poverty lies with coal. Sydney Morning Herald, $5 / 05 / 2014$

TAN, G. 2012. Adani seeks EAC help to fund Abbot Point. The Australian.

WAGNER, L. \& FOSTER, J. 2011. Is There an Optimal Entry Time for Carbon Capture and Storage? A Case Study for Australia's National Electricity Market. Brisbane, Australia: University of Queensland, Australia. 
WILLIAMS, D. 2014. Germany pledges to end development funding of new coal plants. Power Engineering International, 6 October 2014.

WILLIAMS, D. 2015. France confirms end to subsidies for coal plants abroad. Power Engineering International, 9 Febrary 2015.

WORLDBANK 2013. India: Diagnostic Assessment of Select Environmental Challenges. Washington, DC: WorldBank.

YUKHANANOV, A. \& VOLCOVICI, V. 2013. World bank to limit financing of coal-fired plants. Reuters, 16 July 2013. 
Table 1: Variables involved in calculation of WACC and LCOE

\begin{tabular}{|l|l|l|l|}
\hline Component & Symbol & Australia & India \\
\hline Liabilities & $\mathrm{L}$ & $100 \%$ & $100 \%$ \\
Debt & $\mathrm{D}$ & $60 \%$ & $60 \%$ \\
Equity & $\mathrm{E}$ & $40 \%$ & $40 \%$ \\
Risk free Rate of return (RoR) & $\mathrm{RoR}$ & $3.72 \%$ & $7.70 \%$ \\
Market risk premium & & $6 \%$ & $9.05 \%$ \\
Market RoR & & $9.72 \%$ & $16.75 \%$ \\
Corporate tax rate & & $30.0 \%$ & $33.99 \%$ \\
Effective tax rate & $\mathrm{T}$ & $22.5 \%$ & $18.50 \%$ \\
Debt basis point Premium & & $2.95 \%$ & $3.30 \%$ \\
Cost of debt & $\mathrm{R}_{\mathrm{d}}$ & $6.67 \%$ & $11 \%$ \\
Gamma & $\Gamma$ & 0.5 & 0.5 \\
Asset Beta & $\beta_{\mathrm{a}}$ & 0.8 & 0.86 \\
Debt beta & $\beta_{\mathrm{d}}$ & 0.06 & -0.497 \\
Equity Beta & $\beta_{\mathrm{e}}$ & 1.6 & 1.91 \\
Required return on equity CAPM & $\mathrm{R}_{\mathrm{e}}$ & $13.33 \%$ & 25.37 \\
Inflation & CPI & $2.50 \%$ & $5.7 \%$ \\
WACC Post-Tax nominal & & $7.76 \%$ & $14.49 \%$ \\
WACC Post-Tax real & & $5.13 \%$ & $8.32 \%$ \\
\hline
\end{tabular}


Table 2: Bihar electricity tariffs and profitability

\begin{tabular}{|lllll|}
\hline & $\mathbf{2 0 1 0} / \mathbf{1 1}$ & $\mathbf{2 0 1 1 / 1 2}$ & $\mathbf{2 0 1 2 / 3}$ & $\mathbf{2 0 1 3 / 4}$ \\
\hline $\begin{array}{l}\text { Domestic tariff } \\
\text { Rs/kWh (US\$/kWh) }\end{array}$ & $2.14(0.036)$ & $3.19(0.053)$ & $2.86(0.048)$ & $3.29(0.055)$ \\
\hline $\begin{array}{l}\text { Average tariff } \\
\text { Rs/kWh (US\$/kWh) }\end{array}$ & $3.87(0.065)$ & $4.64(0.077)$ & $4.51(0.075)$ & $5.16(0.086)$ \\
\hline $\begin{array}{l}\text { Cost of supply } \\
\text { Rs/kWh (US\$/kWh) }\end{array}$ & $8.61(0.144)$ & $11.71(0.195)$ & $8.64(0.144)$ & $7.85(0.131)$ \\
\hline $\begin{array}{l}\text { Loss on operation } \\
\text { Rs million } \\
\text { US\$ million }\end{array}$ & $\begin{array}{l}(27,488) \\
\text { Source: (Planning Commission, } 2014 a)\end{array}$ & $\begin{array}{l}(45,389) \\
(\$ 756)\end{array}$ & $\begin{array}{l}(31,700) \\
(\$ 528)\end{array}$ & $(25,862)$ \\
\hline
\end{tabular}


Table 3: Coal fired power station capacity, fuel and investment requirements

\begin{tabular}{|c|c|c|c|}
\hline \multicolumn{4}{|c|}{ Projected demand and new capacity required for Bihar } \\
\hline Requirement & Calculation & $\begin{array}{r}\text { Demand } \\
(0.675 \mathrm{~kW} / \text { house })\end{array}$ & $\begin{array}{r}\text { Demand } \\
(0.3 \mathrm{~kW} / \text { house })\end{array}$ \\
\hline Electricity for all households & $\begin{array}{l}0.675 \mathrm{~kW} \times 18,940,629 \\
0.3 \mathrm{~kW} \times 18,940,629\end{array}$ & $12,785 \mathrm{MW}$ & $5,682 \mathrm{MW}$ \\
\hline Headroom & $10 \%$ & $14,063 \mathrm{MW}$ & $6,250 \mathrm{MW}$ \\
\hline Existing in-state & $500 \mathrm{MW}+1,273 \mathrm{MW}$ & $1,773 \mathrm{MW}$ & $1,773 \mathrm{MW}$ \\
\hline Planned in-state & $2,712 \mathrm{MW}$ & $2,712 \mathrm{MW}$ & $2,712 \mathrm{MW}$ \\
\hline Demand un-met & & 9,579MW & $1,765 \mathrm{MW}$ \\
\hline \multicolumn{4}{|c|}{ Source of installed capacity data:(Bihar State Power Company, 2012) } \\
\hline \multicolumn{4}{|c|}{ Fuel requirements for Bihar } \\
\hline & Calculation & $\begin{array}{r}\text { Demand } \\
(0.675 \mathrm{~kW} / \text { house })\end{array}$ & $\begin{array}{r}\text { Demand } \\
(0.3 \mathrm{~kW} / \text { house })\end{array}$ \\
\hline New generation capacity (MW) & & 12,290 & 4,477 \\
\hline Annual generation (GWh) & $67 \%$ capacity & 72,135 & 26,279 \\
\hline Annual fuel requirement (PJ) & $37 \%$ thermal efficiency & 701,853 & 255,686 \\
\hline Galilee coal energy content GJ/t & $5260 \mathrm{kCal} / \mathrm{kg}$ & 22.02 & 22.02 \\
\hline $\begin{array}{l}\text { Annual Galilee coal consumption } \\
\text { (mtpa) }\end{array}$ & & 31.870 & 11.610 \\
\hline \multicolumn{4}{|c|}{ Capital costs for coal-fired generation } \\
\hline & $\begin{array}{r}\text { Unit Cost } \\
\text { US\$/kW }\end{array}$ & $\begin{array}{r}\text { Demand } \\
(0.675 \mathrm{~kW} / \text { house })\end{array}$ & $\begin{array}{r}\text { Demand } \\
(0.3 \mathrm{~kW} / \text { house })\end{array}$ \\
\hline Investment reqd (\$bn) & $\$ 1,200$ & $\$ 14.7$ & $\$ 5.4$ \\
\hline
\end{tabular}


Table 4: Network investment required

Rupees

Cost of transmission and distribution included in proposal for next 10 years

Absolute cost of transmission 2009-18 in bn

Absolute cost of distribution 2010-14 in bn

Total Cost of Transmission and distribution

$\$ 127$

$\$ 2.1$

investment

Source for network investment required: (SNC-Lavalin, 2010) 


\begin{tabular}{|c|c|c|}
\hline & $\begin{array}{r}\text { Capital Costs } \\
\text { (US\$) (Demand } \\
0.675 \mathrm{~kW} / \text { house) }\end{array}$ & $\begin{array}{r}\text { Capital Costs } \\
\text { (US\$) (Demand } \\
0.3 \mathrm{~kW} / \text { house) }\end{array}$ \\
\hline $\begin{array}{l}\text { Carmichael Mine Investment } \\
\text { US\$6.2 billion apportioned for Bihar } \\
\text { component }\end{array}$ & $\$ 3.3$ billion & $\$ 1.2$ billion \\
\hline $\begin{array}{l}\text { Rail corridor } \\
\text { US\$0.9 billion apportioned for Bihar } \\
\text { component }\end{array}$ & $\$ 0.5$ billion & $\$ 0.2$ billion \\
\hline $\begin{array}{l}\text { Abbot point investment and expansion } \\
\text { US\$2 billion apportioned for Bihar component }\end{array}$ & $\$ 0.8$ billion & $\$ 0.3$ billion \\
\hline Shipping to Kolkata & $\mathrm{n} / \mathrm{a}$ & \\
\hline $\begin{array}{l}\text { Barge infrastructure required to Bihar } \\
\text { Rs5760million for } 3 m \text { tpa extrapolated }\end{array}$ & $\$ 1.0$ billion & $\$ 0.4$ billion \\
\hline Capital costs coal-fired power stations & $\$ 14.7$ billion & $\$ 5.4$ billion \\
\hline $\begin{array}{l}\text { Network costs } \\
\text { US\$2.1 billion to reach } 5.4 G W \text { demand } \\
\text { extrapolated for higher demand }\end{array}$ & $\$ 6.3$ billion & $\$ 2.1$ billion \\
\hline TOTAL COST & \$26.6 billion & $\$ 9.6$ billion \\
\hline
\end{tabular}


Table 6: Carbon emissions and cost from coal-fired generation

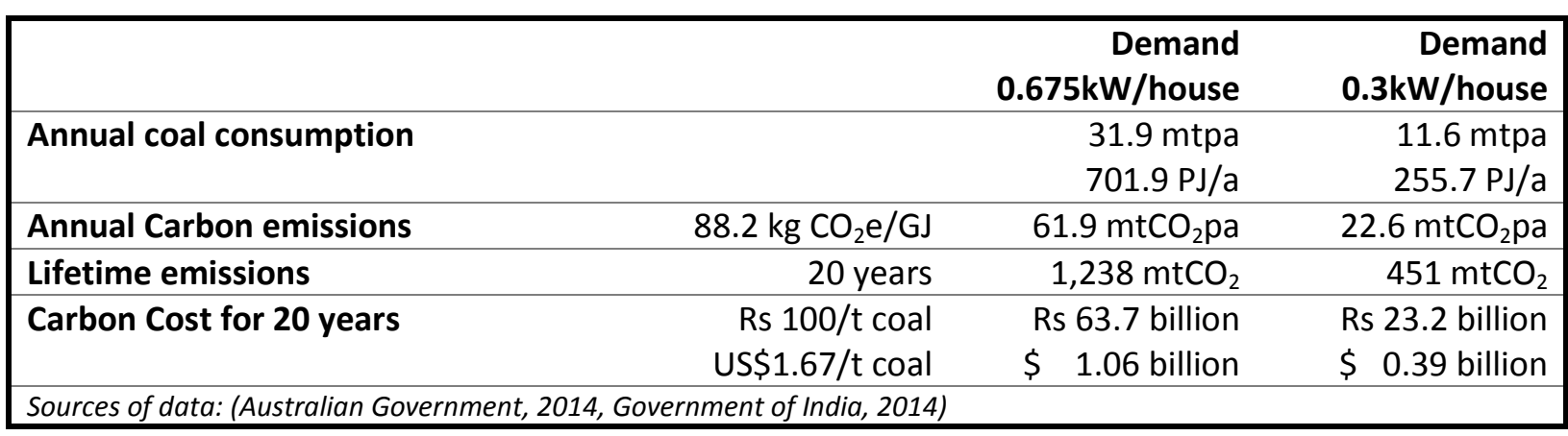


Table 7: Pollutants and the costs of pollution from coal-fired power stations

\begin{tabular}{|c|c|c|c|}
\hline \multicolumn{4}{|c|}{ Electricity usage } \\
\hline & $\begin{array}{r}\text { Demand } \\
(0.675 \mathrm{~kW} / \text { house }) \\
\end{array}$ & $\begin{array}{r}\text { Demand } \\
(0.3 \mathrm{~kW} / \text { house }) \\
\end{array}$ & $\begin{array}{r}\text { China } \\
2012 \\
\end{array}$ \\
\hline Population & $104,099,452$ & $104,099,452$ & $1,354,040,000$ \\
\hline GWh generated all sources & 87,665 & 41,809 & $4,984,772$ \\
\hline kWh/Person & 842 & 402 & 3,681 \\
\hline \multicolumn{4}{|c|}{ Sources of India data: (Planning Commission, 2014b, Planning Commission, 2014a) } \\
\hline \multicolumn{4}{|c|}{ Sources of China data: (National Bureau of Statistics of China, 2013, IEA, 2015) } \\
\hline \multicolumn{4}{|c|}{ Pollutants associated with generation } \\
\hline $\begin{array}{l}\text { Queensland } \\
\text { Kg/MWh }\end{array}$ & $\begin{array}{r}\text { Demand } \\
(0.675 \mathrm{~kW} / \text { house })\end{array}$ & $\begin{array}{r}\text { Demand } \\
(0.3 \mathrm{~kW} / \text { house })\end{array}$ & $\begin{array}{r}\text { China } \\
2012\end{array}$ \\
\hline GWh generated & $\begin{array}{r}72,135 \\
\text { (new installs) }\end{array}$ & $\begin{array}{r}26,279 \\
\text { (new installs) }\end{array}$ & $\begin{array}{l}3,784,933 \\
\text { (coal only) }\end{array}$ \\
\hline $\mathrm{NO}_{\mathrm{x}} \mathrm{mtpa}$ & 0.16 & 0.06 & 23.28 \\
\hline $\mathrm{SO}_{2} \mathrm{mtpa}$ & 0.21 & 0.08 & 21.18 \\
\hline Partic. tpa & 2,780 & 1,013 & $\mathrm{n} / \mathrm{a}$ \\
\hline Landmass (sq.km) & 94,197 & 94,197 & $9,506,931$ \\
\hline $\mathrm{Kg} \mathrm{NO} / \mathrm{sq} \cdot \mathrm{km}$ & 1,712 & 623 & 2,459 \\
\hline $\mathrm{Kg} \mathrm{SO}_{2} / \mathrm{sq} . \mathrm{km}$ & 2,214 & 806 & 2,227 \\
\hline \multicolumn{4}{|c|}{$\begin{array}{l}\text { Sources for coal properties: (Bureau of Mining and Petroleum, 2003) } \\
\text { Sources for emissions: (Stanwell Corporation, 2013, CS Energy, 2013, Australian Government, 2013) } \\
\text { Source for China data: (IEA, 2015, National Bureau of Statistics of China, 2013) }\end{array}$} \\
\hline \multicolumn{4}{|c|}{ Cost associated with reducing $\mathrm{SO}_{2}, \mathrm{NO}_{\mathrm{x}}$ and particulate emissions } \\
\hline & $\begin{array}{r}\text { Demand } \\
(0.675 \mathrm{~kW} / \text { house })\end{array}$ & $\begin{array}{r}\text { Demand } \\
(0.3 \mathrm{~kW} / \text { house })\end{array}$ & $\begin{array}{r}\text { China } \\
2012 \\
\end{array}$ \\
\hline Pollution cost per GW \$ & $\$ 351$ & $\$ 351$ & $\$ 351$ \\
\hline Coal-fired power stations (GW) & 14.06 & 6.25 & 791 \\
\hline Cost to reduce pollution $\$$ bn & $\$ 4.94$ & $\$ 2.20$ & $\$ 278$ \\
\hline \multicolumn{4}{|l|}{ Sources for China data:(Chen et al., IEA, 2014c) } \\
\hline \multicolumn{4}{|c|}{ Cost associated with lives lost from pollution } \\
\hline Potential loss of life from pollution & $\begin{array}{r}27,000- \\
39,000\end{array}$ & & $\begin{array}{r}350,000- \\
500,000\end{array}$ \\
\hline Value of life $\$$ & $\$ 150,000$ & & \\
\hline Value of lives lost \$bn & $\$ 4.95$ & & \\
\hline \multicolumn{4}{|c|}{ Source for India data: (Madheswaran, 2007, WorldBank, 2013) } \\
\hline \multicolumn{4}{|c|}{ Health and productivity loss costs of pollution } \\
\hline Economic drag on economy & $1.7 \%$ & $0.6 \%$ & $5-14 \%$ \\
\hline GDP in $2019 \$$ bn & $\$ 92$ & $\$ 92$ & \\
\hline Annual cost of health/prod loss \$bn & $\$ 1.5$ & $\$ 0.6$ & \\
\hline $\begin{array}{l}\text { Sources for China data: (Matus et al., 2012) } \\
\text { Sources for India data: (Planning Commission, 2014 }\end{array}$ & & & \\
\hline
\end{tabular}


Table 8: Employment potential from constructing and operating coal-fired power stations

\begin{tabular}{|lrr|}
\hline & $\begin{array}{r}\text { Demand } \\
(\mathbf{0 . 6 7 5 k W )}\end{array}$ & $\begin{array}{r}\text { Demand } \\
\text { (0.3kW) }\end{array}$ \\
\hline Avg employment /1000MW & 543 & 543 \\
\hline Employment opportunity & 6,670 & 2,430 \\
\hline Source of employment data:(Bihar Government, 2014) & & \\
\hline
\end{tabular}


Table 9: Calculating capacity and cost of decentralised renewable energy requirement

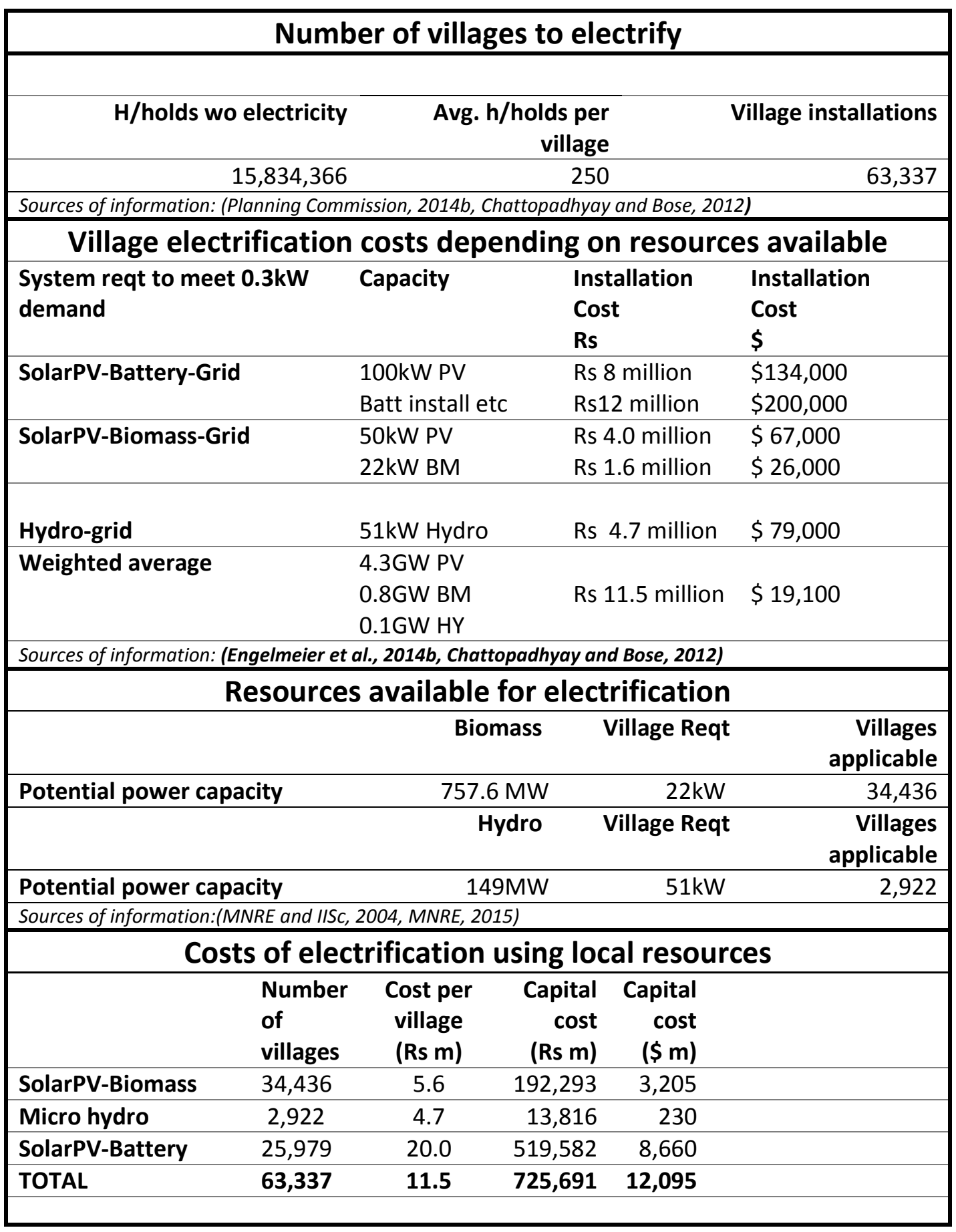




\begin{tabular}{|c|c|c|c|}
\hline \multicolumn{4}{|c|}{ Estimating employment benefit in numbers } \\
\hline & & \multicolumn{2}{|c|}{$\begin{array}{r}\text { Decentralised Renew } \\
\text { (Demand 0.3kW) }\end{array}$} \\
\hline \multicolumn{4}{|l|}{ Potential employment using BSIPB Proposals } \\
\hline Average employment / GW & & & 15,137 \\
\hline GW investment & & & 5.2 \\
\hline Employment opportunity & & & 79,110 \\
\hline \multicolumn{4}{|l|}{ Potential employment using Bangladesh model } \\
\hline Average employment / 1000 houses & & & 38 \\
\hline Non-electrified houses & & & $15,834,366$ \\
\hline Employment opportunity & & & 601,706 \\
\hline \multicolumn{4}{|l|}{$\begin{array}{l}\text { Source for Bihar Investment data: (Bihar Government, 2014) } \\
\text { Source for Bangladesh data: (IRENA, 2014, Sadeque et al., 2014) }\end{array}$} \\
\hline \multicolumn{4}{|c|}{ Estimating employment benefit in value } \\
\hline 2011 & 2015 & 2016 & 2024 \\
\hline Population (million) & & & \\
\hline Population under 6 & & & \\
\hline Project population under 16 & & & \\
\hline Assume working population & & & \\
\hline GDP (10\% pa growth) Rs bn & 3,774 & 4,151 & 8,898 \\
\hline GDP/adult (Rs) & 80,809 & 88,890 & 190,544 \\
\hline Employment potential & 75,000 & 75,000 & 75,000 \\
\hline Income potential (Rs bn) & 6.06 & 6.67 & 14.29 \\
\hline \multicolumn{4}{|l|}{ Cumulative benefit over 10 years } \\
\hline \$Rs bn & & & 90.53 \\
\hline US\$ bn & & & 1.61 \\
\hline
\end{tabular}


Table 11: All up cost comparison: investment costs

\begin{tabular}{|lrr|}
\hline & $\begin{array}{c}\text { Coal generation } \\
\text { Demand 0.675kW }\end{array}$ & $\begin{array}{r}\text { Decentralised } \\
\text { generation } \\
\text { Demand 0.675kW }\end{array}$ \\
\hline Mining extraction investment \$bn & 3.3 & 0.0 \\
\hline Transport related investment Australia \$bn & 1.3 & \\
\hline Transport related investment India \$bn & 1.0 & \\
\hline Capital costs relating to mining/transport & 5.6 & \\
\hline & & \\
\hline Power station investment \$bn & 14.7 & \\
\hline Network investment \$bn & 6.3 & \\
\hline Capital costs relating to electrification & $\mathbf{2 1 . 0}$ & \\
\hline & & \\
\hline Cost of carbon emissions for 20 years & 1.1 & \\
\hline Cost of other pollutants for 20 years & 4.9 & 0.0 \\
\hline Value of lives lost for 10 years & 49.5 & \\
\hline Cost of health/productivity loss for 10 years & 15.2 & $\mathbf{2 7 . 5}$ \\
\hline TOTAL POLLUTION RELATED COSTS \$bn & $\mathbf{7 0 . 7}$ & 3.22 \\
\hline
\end{tabular}


Table 12: Cost of coal from Galilee Basin delivered to Bihar, India

\begin{tabular}{|lrr|}
\hline Coal process & AU\$/tonne & US\$/tonne \\
\hline $\begin{array}{l}\text { Mined cost (including overhead and } \\
\text { interest) }\end{array}$ & 54.57 & $\$ 43.66$ \\
\hline Rail to Abbot Point & & $\$ 11.98$ \\
\hline Port costs & 14.97 & $\$ 7.50$ \\
\hline Royalty to Queensland Government & 9.38 & $\$ 3.06$ \\
\hline Transport to East Coast India & 3.82 & $\$ 13.50$ \\
\hline Transport to Bihar (840km) & 16.88 & $\$ 21.39$ \\
\hline TOTAL COST DELIVERED TO BIHAR & 25.45 & $\mathbf{\$ 9 3 . 5 8}$ \\
\hline
\end{tabular}

Sources for coal mining, port and rail costs: (GHD Pty Ltd, 2013, Aurizon, 2014)

Source for sea transport costs:(ArgusMedia, 2014)

Sources for Indian transportation costs: (Indian Railways, 2014, Indian Railways, 2015, Gazette of India, 2011) 
Table 13: Costs to distribute power to consumers

\begin{tabular}{|c|c|c|}
\hline & Rupees & US\$ \\
\hline \multicolumn{3}{|l|}{ Cost of network included in existing tariff } \\
\hline Cost per kWh & 1.59 & $\$ 0.027$ \\
\hline $\begin{array}{l}\text { Network cost/kWh required for new } \\
\text { investment }\end{array}$ & 0.54 & $\$ 0.009$ \\
\hline $\begin{array}{l}\text { Cost of lost energy generated at } 20 \% \\
\text { network losses }\end{array}$ & 0.96 & $\$ 0.016$ \\
\hline Total Cost of Transmission and distribution & 3.09 & $\$ 0.052$ \\
\hline $\begin{array}{l}\text { Source for electricity existing costs: (Planning Commission, 2014a) } \\
\text { Source for network investment required: (SNC-Lavalin, 2010) }\end{array}$ & & \\
\hline
\end{tabular}


Table 14: Levelised cost of decentralised electricity for Bihar

\begin{tabular}{|lrr|}
\hline Installation type & $\begin{array}{c}\text { LCOE } \\
\text { Rupees/kWh }\end{array}$ & LCOE \$/kWh \\
\hline SolarPV-Biomass & 5.16 & 0.086 \\
\hline Micro-Hydro & 2.94 & 0.049 \\
\hline SolarPV-Battery & 14.10 & 0.235 \\
\hline AVERAGED TOTAL & 8.10 & 0.135 \\
\hline Sources: (Chattopadhyay and Bose, 2012, Engelmeier et al., 2014b, IRENA, 2012a, IRENA, 2012b) & \\
\hline
\end{tabular}


Table 15: All-up cost comparison: cost/kWh

\begin{tabular}{|c|c|c|}
\hline & $\begin{array}{r}\text { Coal generation } \\
\text { Demand } \\
0.675 \mathrm{~kW} \$ / \mathrm{kWh}\end{array}$ & $\begin{array}{r}\text { Decentralised } \\
\text { generation } \\
\text { Demand } 0.675 \mathrm{~kW} \\
\$ / \mathrm{kWh} \\
\end{array}$ \\
\hline Cost of generation & 0.083 & 0.135 \\
\hline Network costs & 0.052 & 0.00 \\
\hline DIRECT COST OF ELECTRIFICATION & 0.135 & 0.135 \\
\hline Carbon cost & 0.001 & 0.00 \\
\hline Coal-generation pollution control cost & 0.004 & 0.00 \\
\hline Value of lives lost & 0.080 & 0.00 \\
\hline Economic drag of health and productivity loss & 0.025 & 0.00 \\
\hline EXTERNAL COST OF ELECTRIFICATION & 0.110 & 0.00 \\
\hline TOTAL COST OF ELECTRIFICATION & 0.245 & 0.135 \\
\hline
\end{tabular}

